Katarzyna Lomper, Anna Chudiak, Izabella Uchmanowicz, Joanna Rosińczuk, Beata Jankowska-Polanska

Department of Clinical Nursing, Faculty of Health Science, Wroclaw Medical University, Poland

\title{
Effects of depression and anxiety on asthma-related quality of life
}

The authors declare no financial disclosure

\begin{abstract}
Introduction: Asthma is the most prevalent chronic disease in adults. It affects their quality of life. Studies confirm that depression and anxiety occurs in asthma patients.

Material and methods: The study involved 96 patients with asthma divided into two groups: patients with controlled $(n=33)$ and uncontrolled asthma $(n=63)$. The analysis of asthma control was performed on the basis of the ACT (Asthma Control Test) results. The study used SF-36 (Short Form 36) questionnaire and HADS (Hospital and Depression Scale) Scale.

Results: An analysis of the correlations between OoL (Quality of Life) and the level of depression revealed a decrease in $0 \mathrm{oL}$ scores in MCS (Mental Component Score) domain in the group with controlled asthma (71.8 — patients without depression, 53.4 - patients with probable depression, and 51.4 — patients with depression; $p=0.032$ ). A similar analysis of the correlations between $\mathrm{OoL}$ and the level of anxiety in this group of patients proved no correlations in PCS (Physical Component Score) and MCS domains. In the group of patients with uncontrolled asthma, anxiety and depression correlated negatively with the $0 \mathrm{oL}$ in PCS and MCS domains. Anxiety and depression are found in asthma patients, with higher severity observed in patients with uncontrolled asthma. Female gender, the level of asthma control, asthma severity, smoking, as well as diagnoses of anxiety and depression are predictors of a significantly lower $0 \mathrm{oL}$ in asthma.

Conclusions: Anxiety and depression are found in asthma patients, with higher severity observed in patients with uncontrolled asthma. Female gender, the level of asthma control, asthma severity, smoking, as well as diagnoses of anxiety and depression are predictors of a significantly lower quality of life in asthma.
\end{abstract}

Key words: asthma, quality of life, depression, anxiety

Pneumonol Alergol Pol 2016; 84: 212-221

\section{Introduction}

The Global Initiative for Asthma report GINA 2006, has completely changed an approach to asthma treatment. It recommends the creation of education programs to fully control the disease. Effects of asthma therapy depend on patients' readiness to cooperate with doctors and comply with their orders [1]. Scientific reports show that proper education of patients with bronchial asthma not only increase the level of its control but also substantially improve perceived quality of life. In medical sciences underlines the importan- ce of the Health Realated Quality of Life (HRQoL). The concept of HRQoL is created by Schipper et $a l$. and it is defined as "functional effect of the disease and its treatment received by a patient" [2]. Measurement HRQoL in asthma patients is important. Understanding of factors affecting quality of life allows to schedule treatment plan.

Patients' education on asthma control is a modifiable factor affecting quality of life [3]. Having a written Asthma Action Plan helps to decrease the number of asthmatic bouts and better control the disease. GINA recommends that such plans should be updated once a year [4].

Address for correspondence: Katarzyna Lomper, Department of Clinical Nursing, Faculty of Health Science, Wroclaw Medical University, Poland,

e-mail: katarzyna.lomper@gmail.com

DOI: 10.5603/PiAP.2016.0026

Received: 23.01.2016

Copyright (C) 2016 PTChP

ISSN 0867-7077 
Asthma control is based on the estimation of the frequency and severity of symptoms. Patients should be able to assess the severity of symptoms over time, and know what factors cause the worsening of their health status. It is also useful to keep an asthmatic diary and, in case of patients with severe asthma, to monitor PEF values every day [5]. Unfortunately, the Asthma Insight \& Reality in Europe (AIRE) study, carried out in 29 countries in the world, demonstrated that less than five per cent of patients achieve full asthma control [6].

Efficient therapy for asthma includes the control of both daytime and night-time clinical symptoms, as well as the maintenance of normal life activity of a patient. Full asthma control means: the achievement of overall, current control, and thus reducing the risk of asthma exacerbations; the prevention of early loss of lung function; and no drug related side-effects [7].

Running a variable course and requiring permanent health care, chronic asthma affects all aspects of patients' activity. Available reports prove that patients with bronchial asthma have a low quality of life. Furthermore, many researchers assert that there is a relationship between mental state of asthma patients and symptoms of primary disease, its dynamics, and treatment efficiency. In many cases, airway obstruction episodes are of emotional origin [8-10].

Co-existence of somatic and mental disorders results in a more serious course of the disease and often more severe symptoms, while psychopathological factors (anxiety and depression) condition subjective feelings of patients.

Numerous publications are available, which assess the quality of life of patients with bronchial asthma, while there are only few which describe how the level of asthma control affects quality of life and ability to deal with feelings of stress, frequently associated with asthma. In our study we just wanted to show that good control of asthma is not the only requirement for good clinical outcome, but improving the quality of life and reducing stress level are also important.

\section{Material and methods}

The study involved 96 patients with bronchial asthma treated in the Allergology Outpatient Clinic of the Lower Silesian Centre of Lung Diseases in Wroclaw.

The criteria for inclusion in the study were: asthma diagnosis, severity of symptoms, the level of symptom control determined according to the GINA guidelines of 2012, and 18 years of age or more.
The patients were divided into two groups: - group C - patients with controlled asthma $(n=33)$ - results of the Asthma Control Test (ACT) ranging from 25 to 20 points

- group U - patients with uncontrolled asthma $(\mathrm{n}=63)$ - the ACT results below 20 points.

An analysis of asthma control was performed on the basis of the ACT results. Patients can obtain a maximum of 25 points, which is a score reflecting full control of the disease. Scores of 24-20 mean that asthma is well- but not fully-controlled, and scores below 20 show that the disease is poorly controlled [11].

The quality of life was assessed with the Short Form-36 questionnaire (SF-36), which consists of 36 questions (items) concerning two aspects of quality of life: physical (Physical Component Score, PCS) and mental (Mental Component Score, MCS). In each category the score can range from 0 to 100 - the lower the score, the worse the quality of life [12].

The levels of anxiety and depression were determined using The Hospital Anxiety and Depression Scale (HADS). There are two subscales within this measure, each of them including seven statements related to the current emotional status. The scores are interpreted as follows: $0-7=$ normal levels of anxiety and depression; $8-10=$ borderline abnormal levels of anxiety and depression, and $11-21=$ abnormal levels of anxiety and depression [13].

A statistical analysis of the results was performed using STATISTICA 10 and an Excel spreadsheet.

The study described in the article was approved by the Bioethical Commission of the Medical University of Wroclaw (no. KB-154/2013).

\section{Results}

A profile of asthma patients in relation to the level of symptom control is shown in Table 1.

A clinical analysis proved that patients in group $\mathrm{C}$ were more often diagnosed as having intermittent asthma $(27.3 \%)$ and chronic mild asthma (42.4\%), while patients in group U had usually chronic moderate asthma (31.8\%) and chronic severe asthma (34.9\%). An average duration of asthma was longer in group $\mathrm{U}(12.7 \pm$ 12.2 vs. $7.2 \pm 9.4 ; p=0.001$ ). Over $30 \%$ of group $\mathrm{U}$ had night-time asthma symptoms several times a week. In group C, night-time asthma symptoms occurred rarer than once a month in $48.5 \%$ of patients. In group U, nearly $40 \%$ of patients were 
Table 1. A profile of asthma patients in relation to the level of symptom control

\begin{tabular}{|c|c|c|c|}
\hline Feature & $\begin{array}{l}\text { With controlled asthma } \\
\text { (C) } \\
n=33\end{array}$ & $\begin{array}{l}\text { With uncontrolled astma } \\
\qquad \begin{array}{c}(\mathrm{U}) \\
n=63\end{array} \\
\end{array}$ & $\begin{array}{c}\text { Comparison } \\
\text { C vs. U } \\
\text { p }\end{array}$ \\
\hline $\begin{array}{l}\text { Gender: } \\
\text { Women } \\
\text { Men }\end{array}$ & $\begin{array}{l}19(57.6 \%) \\
14(42.4 \%)\end{array}$ & $\begin{array}{l}41(65.1 \%) \\
22(34.9 \%)\end{array}$ & 0.618 \\
\hline $\begin{array}{l}\text { Age [year of life] } \\
\text { mean } \pm S D\end{array}$ & $49.4 \pm 18.5$ & $58.0 \pm 16.4$ & 0.022 \\
\hline $\begin{array}{l}\text { Education: } \\
\text { primary } \\
\text { vocational } \\
\text { secondary } \\
\text { higher }\end{array}$ & $\begin{array}{c}3(9.1 \%) \\
2(6.1 \%) \\
16(48.5 \%) \\
12(36.4 \%)\end{array}$ & $\begin{array}{c}13(20.6 \%) \\
26(41.3 \%) \\
18(28.6 \%) \\
6(9.5 \%)\end{array}$ & $<0.001$ \\
\hline $\begin{array}{l}\text { Professional activity: } \\
\text { 1. yes } \\
\text { 2. no }\end{array}$ & $\begin{array}{l}18(54.6 \%) \\
15(45.4 \%)\end{array}$ & $\begin{array}{l}14(22.2 \%) \\
49(77.8 \%)\end{array}$ & 0.003 \\
\hline $\begin{array}{l}\text { Type of actual profession: } \\
\text { 1. manual } \\
\text { 2. non-manual }\end{array}$ & $\begin{array}{l}14(42.4 \%) \\
19(57.6 \%)\end{array}$ & $\begin{array}{l}47(74.6 \%) \\
16(25.4 \%)\end{array}$ & 0.009 \\
\hline $\begin{array}{l}\text { Type of asthma: } \\
\text { intermittent } \\
\text { chronic mild } \\
\text { chronic moderate } \\
\text { chronic severe }\end{array}$ & $\begin{array}{c}9(27.3 \%) \\
14(42.4 \%) \\
6(18.2 \%) \\
4(12.1 \%)\end{array}$ & $\begin{array}{c}3(4.8 \%) \\
18(28.6 \%) \\
20(31.8 \%) \\
22(34.9 \%)\end{array}$ & 0.001 \\
\hline $\begin{array}{l}\text { Smoking: } \\
0 . \text { no } \\
\text { 1. no more } \\
\text { 2. yes }\end{array}$ & $\begin{array}{c}27(81.8 \%) \\
6(18.2 \%) \\
0(0.0 \%)\end{array}$ & $\begin{array}{c}30(47.6 \%) \\
24(38.1 \%) \\
9(14.3 \%)\end{array}$ & 0.003 \\
\hline $\begin{array}{l}\text { Duration of smoking [years] } \\
\text { mean } \pm S D \\
\text { median }(\min \pm \max )\end{array}$ & $\begin{array}{c}1.9 \pm 4.6 \\
0(0 \pm 20)\end{array}$ & $\begin{array}{c}6.2 \pm 9.7 \\
2(0 \pm 50)\end{array}$ & 0.007 \\
\hline $\begin{array}{l}\text { Duration of the disease [years] } \\
\text { mean } \pm S D \\
\text { median }(\min \pm \max )\end{array}$ & $\begin{array}{c}7.2 \pm 9.4 \\
4(1 \pm 40)\end{array}$ & $\begin{array}{c}12.7 \pm 12.2 \\
9(1 \pm 60)\end{array}$ & 0.001 \\
\hline $\begin{array}{l}\text { How often do night-time asthma symptoms occur? } \\
\text { 1. less than once a month and they are short-lived } \\
\text { 2. more than twice a month; they can disturb sleep and hin- } \\
\text { der daytime activity } \\
\text { 3. more than once a week } \\
\text { 4. } 2 \text {-3 times a week or more }\end{array}$ & $\begin{array}{l}16(48.5 \%) \\
8(24.2 \%) \\
7(21.2 \%) \\
2(6.1 \%)\end{array}$ & $\begin{array}{l}18(28.6 \%) \\
13(20.6 \%) \\
12(19.0 \%) \\
20(31.8 \%)\end{array}$ & 0.043 \\
\hline $\begin{array}{l}\text { The frequency of visits to the Allergology Outpatient } \\
\text { Clinic: } \\
\text { 1. once or twice a month } \\
\text { 2. six times a year } \\
\text { 3. three times a year } \\
\text { 4. rarer }\end{array}$ & $\begin{array}{c}4(12.1 \%) \\
9(27.3 \%) \\
19(57.6 \%) \\
1(3.0 \%)\end{array}$ & $\begin{array}{l}21(33.4 \%) \\
13(20.6 \%) \\
16(25.4 \%) \\
13(20.6 \%)\end{array}$ & 0.005 \\
\hline $\begin{array}{l}\text { Stays in hospital due to asthma: } \\
\text { no stays } \\
1-2 \text { times } \\
3-5 \text { times } \\
6 \text { or more times }\end{array}$ & $\begin{array}{c}13(39.4 \%) \\
16(48.4 \%) \\
2(6.1 \%) \\
2(6.1 \%)\end{array}$ & $\begin{array}{c}5(7.9 \%) \\
21(33.3 \%) \\
12(19.1 \%) \\
25(39.7 \%)\end{array}$ & $<0.001$ \\
\hline
\end{tabular}


Table 2. Quality of life analysis performed with the SF-36 in relation to the level of asthma control

\begin{tabular}{|c|c|c|c|}
\hline $\begin{array}{l}\text { The questionnaire } \\
\text { domains }\end{array}$ & $\begin{array}{l}\text { With controlled asthma } \\
\qquad \begin{array}{l}\text { (C) } \\
n=33\end{array}\end{array}$ & $\begin{array}{l}\text { With uncontrolled asthma } \\
\text { (U) } \\
n=58\end{array}$ & $\begin{array}{c}\text { Comparison } \\
\text { C vs. U } \\
\text { p }\end{array}$ \\
\hline $\begin{array}{c}\text { PF } \\
\text { mean } \pm \text { SD } \\
\text { median }(\min \pm \max )\end{array}$ & $\begin{array}{c}64.7 \pm 30.9 \\
80(0 \pm 100)\end{array}$ & $\begin{array}{c}39.0 \pm 29.1 \\
35(0 \pm 100)\end{array}$ & $<0.001$ \\
\hline $\begin{array}{c}\mathbf{R P} \\
\text { mean } \pm \mathrm{SD} \\
\text { median }(\min \pm \max )\end{array}$ & $\begin{array}{c}50.8 \pm 39.3 \\
50(0 \pm 100)\end{array}$ & $\begin{array}{l}30.2 \pm 39.2 \\
0(0 \pm 100)\end{array}$ & 0.015 \\
\hline $\begin{array}{c}\text { BP } \\
\text { mean } \pm \text { SD } \\
\text { median }(\min \pm \max )\end{array}$ & $\begin{array}{c}64.1 \pm 25.8 \\
62(10 \pm 100)\end{array}$ & $\begin{array}{c}46.4 \pm 25.9 \\
41(0 \pm 100)\end{array}$ & 0.001 \\
\hline $\begin{array}{c}\text { VT } \\
\text { mean } \pm S D \\
\text { median }(\min \pm \max )\end{array}$ & $\begin{array}{c}56.1 \pm 13.7 \\
55(35 \pm 90)\end{array}$ & $\begin{array}{l}43.5 \pm 23.1 \\
45(0 \pm 85)\end{array}$ & 0.014 \\
\hline $\begin{array}{c}\mathbf{G H} \\
\text { mean } \pm \mathrm{SD} \\
\text { median }(\min \pm \max )\end{array}$ & $\begin{array}{c}43.9 \pm 14.4 \\
45(10 \pm 67)\end{array}$ & $\begin{array}{l}36.1 \pm 16.7 \\
35(0 \pm 75)\end{array}$ & 0.013 \\
\hline $\begin{array}{c}\text { SF } \\
\text { mean } \pm \text { SD } \\
\text { median }(\min \pm \max )\end{array}$ & $\begin{array}{c}66.7 \pm 25.3 \\
75(0 \pm 100)\end{array}$ & $\begin{array}{c}48.4 \pm 30.4 \\
50(0 \pm 100)\end{array}$ & 0.004 \\
\hline $\begin{array}{c}\mathbf{R E} \\
\text { mean } \pm \text { SD } \\
\text { median }(\min \pm \max )\end{array}$ & $\begin{array}{c}62.6 \pm 41.5 \\
67(0 \pm 100)\end{array}$ & $\begin{array}{l}52.9 \pm 43.4 \\
67(0 \pm 100)\end{array}$ & 0.296 \\
\hline $\begin{array}{c}\text { MH } \\
\text { mean } \pm \text { SD } \\
\text { median }(\min \pm \max )\end{array}$ & $\begin{array}{c}64.8 \pm 17.6 \\
60(32 \pm 96)\end{array}$ & $\begin{array}{c}56.5 \pm 23.6 \\
60(12 \pm 100)\end{array}$ & 0.133 \\
\hline $\begin{array}{c}\text { PCS } \\
\text { mean } \pm \text { SD } \\
\text { median }(\min \pm \max )\end{array}$ & $\begin{array}{c}58.9 \pm 21.1 \\
61(15 \pm 94)\end{array}$ & $\begin{array}{l}39.8 \pm 22.7 \\
38(3 \pm 91)\end{array}$ & $<0.001$ \\
\hline $\begin{array}{c}\text { MCS } \\
\text { mean } \pm \text { SD } \\
\text { median }(\min \pm \max )\end{array}$ & $\begin{array}{c}59.5 \pm 20.0 \\
64(25 \pm 87)\end{array}$ & $\begin{array}{c}48.5 \pm 21.6 \\
47(10 \pm 86)\end{array}$ & 0.023 \\
\hline
\end{tabular}

$\mathrm{PF}$ — physical functioning; RP — role limitations due to physical problems; $\mathrm{BP}$ — bodily pain; $\mathrm{GH}$ — general health perception; VT — vitality; SF — social functioning; $\mathrm{MH}$ - mental health; $\mathrm{RE}$ - role limitation due to emotional problems

hospitalized due to asthma at least six times more frequently than in group $\mathrm{C}$, and $33.4 \%$ visited the Allergology Outpatient Clinic even twice a month. A vast majority of patients in group $C$ had not been hospitalized due to asthma (39.4\%) or were in hospital only once or twice (48.8\%).

The result analysis showed that women predominated in both groups: group $\mathrm{U}-65.1 \%$ and group $\mathrm{C}-57.6 \%, \mathrm{p}=0.618$ (ns). Patients with uncontrolled asthma were also worse educated than those with controlled asthma (primary education: $20.6 \%$ vs. $9.1 \%$ and vocational education: $41.3 \%$ vs. $6.1 \%$ ), and less professionally active (22.2\% vs. $54.6 \%)$.

The analysis revealed that patients with controlled asthma had higher quality of life. The total quality of life score within the physical functioning (PCS) (consisting of the domains: PF, $\mathrm{RP}, \mathrm{BP}, \mathrm{VT}$ ) was higher in group $\mathrm{C}$ than in group U 58.9 (SD 21.1) vs. 39.8 (SD 22.7) respectively. The difference between these values was statistically significant. The above values are shown in table 2. Also the total quality of life score within the mental functioning (MCS) (consisting of the domains: SF, RE, MH, GH) was higher in group C compared to group U $(59.5 \pm 20.0)$ vs. 48.5 ( \pm 21.6 , respectively). The difference between these values was statistically significant. The above values are shown in Table 2 .

The analysis of anxiety and depression performed with the HADS demonstrated statistically significantly higher levels of anxiety $(11.3 \pm 4.4$ 
Table 3. Analysis of anxiety and depression according to the HADS in relation to the level of asthma control

\begin{tabular}{|c|c|c|c|}
\hline Feature & $\begin{array}{l}\text { With controlled asthma } \\
\qquad \begin{array}{l}\text { (C) } \\
n=33\end{array}\end{array}$ & $\begin{array}{l}\text { With uncontrolled asthma } \\
\qquad \begin{array}{l}\text { (U) } \\
n=58\end{array}\end{array}$ & $\begin{array}{l}\text { Comparison } \\
\text { C vs. U } \\
\text { p }\end{array}$ \\
\hline $\begin{array}{l}\text { HADS results - Depression } \\
\text { mean } \pm \text { SD } \\
\text { median }(\min \pm \max )\end{array}$ & $\begin{array}{c}8.9 \pm 4.5 \\
9(1 \pm 19)\end{array}$ & $\begin{array}{c}10.9 \pm 4.8 \\
10(3 \pm 20)\end{array}$ & 0.052 \\
\hline $\begin{array}{l}\text { HADS results - Anxiety } \\
\text { mean } \pm S D \\
\text { median }(\min \pm \max )\end{array}$ & $\begin{array}{l}8.6 \pm 4.7 \\
8(0 \pm 20)\end{array}$ & $\begin{array}{c}11.3 \pm 4.4 \\
11(2 \pm 20)\end{array}$ & 0.007 \\
\hline $\begin{array}{l}\text { HADS results - depression: } \\
\text { no depression } \\
\text { probable depression } \\
\text { definite depression }\end{array}$ & $\begin{array}{l}12(36.4 \%) \\
11(33.3 \%) \\
10(30.3 \%)\end{array}$ & $\begin{array}{l}14(22.2 \%) \\
18(28.6 \%) \\
31(49.2 \%)\end{array}$ & 0.168 \\
\hline $\begin{array}{l}\text { HADS results - anxiety: } \\
\text { no anxiety } \\
\text { probable anxiety } \\
\text { definite anxiety }\end{array}$ & $\begin{array}{l}13(39.4 \%) \\
12(36.4 \%) \\
8(24.2 \%)\end{array}$ & $\begin{array}{l}13(20.6 \%) \\
17(27.0 \%) \\
33(52.4 \%)\end{array}$ & 0.024 \\
\hline
\end{tabular}

HADS - Hospital and Depression Scale

Table 4. Analysis of a correlation between the quality of life score according to the SF-36 and the level of depression

\begin{tabular}{|c|c|c|c|c|}
\hline & \multicolumn{3}{|c|}{ HADS - diagnosis (C) } & \multirow{2}{*}{$\begin{array}{c}\text { Comparison } \\
\text { P }\end{array}$} \\
\hline & $\begin{array}{c}\text { No } \\
\text { depression }\end{array}$ & $\begin{array}{c}\text { Probable } \\
\text { depression }\end{array}$ & $\begin{array}{c}\text { Definite } \\
\text { depression }\end{array}$ & \\
\hline $\begin{array}{l}\text { SF-36 PCS } \\
\text { mean } \pm \text { SD }\end{array}$ & $\begin{array}{c}n=12 \\
68.2 \pm 17.2\end{array}$ & $\begin{array}{c}n=11 \\
46.0 \pm 22.5\end{array}$ & $\begin{array}{c}n=10 \\
61.9 \pm 18.1\end{array}$ & 0.052 \\
\hline \multirow[t]{3}{*}{$\begin{array}{l}\text { SF-36 MCS } \\
\text { mean } \pm \text { SD }\end{array}$} & $\begin{array}{c}n=12 \\
71.8 \pm 12.1\end{array}$ & $\begin{array}{c}n=11 \\
53.4 \pm 21.9\end{array}$ & $\begin{array}{c}n=10 \\
51.4 \pm 19.9\end{array}$ & 0.032 \\
\hline & \multicolumn{3}{|c|}{ HADS — diagnosis (U) } & Comparison \\
\hline & $\begin{array}{c}\text { No } \\
\text { depression }\end{array}$ & $\begin{array}{c}\text { Probable } \\
\text { depression }\end{array}$ & $\begin{array}{c}\text { Definite } \\
\text { depression }\end{array}$ & \\
\hline $\begin{array}{l}\text { SF-36 PCS } \\
\text { mean } \pm \text { SD }\end{array}$ & $\begin{array}{c}n=14 \\
48.6 \pm 25.0\end{array}$ & $\begin{array}{c}n=18 \\
49.2 \pm 21.7\end{array}$ & $\begin{array}{c}n=31 \\
30.3 \pm 18.5\end{array}$ & 0.003 \\
\hline $\begin{array}{l}\text { SF-36 MCS } \\
\text { mean } \pm \text { SD }\end{array}$ & $\begin{array}{c}n=14 \\
57.5 \pm 20.9\end{array}$ & $\begin{array}{c}n=18 \\
53.3 \pm 20.9\end{array}$ & $\begin{array}{c}n=31 \\
33.7 \pm 18.2\end{array}$ & 0.002 \\
\hline
\end{tabular}

HADS — Hospital and Depression Scale; SF-36 — Short Form 36; PCS — Physical Component Score; MCS — Mental Component Score

U vs. $8.6 \pm 4.7 \mathrm{C} ; \mathrm{p}=0.007$ ) in the group of patients with uncontrolled asthma. In the group with uncontrolled asthma definite anxiety was diagnosed in over a half of patients (52.4\%), while in the group with controlled asthma only in 24.2\%; $\mathrm{p}=0.024$ (Table 3).

The analysis of the correlations between quality of life measured with the SF-36 and the level of depression determined with the HADS revealed a decrease in quality of life scores in MCS domain in the group with controlled asthma (71.8 - patients without depression, 53.4 - patients with probable depression, and 51.4 - patients with definite depression; $p=0.032$ ) (Table 4).
In the group with uncontrolled asthma, quality of life scores were lower both in PCS domain (48.6 - patients without depression, 49.2 - patients with probable depression, and 30.3 - patients with definite depression; $\mathrm{p}=0.003$ ), and MCS domain (57.5 — patients without depression, 53.3 - patients with probable depression, and 33.7 - patients with definite depression; $p=0.002$ ). It should be emphasized that patients with uncontrolled asthma and a diagnosis of definite depression obtained significantly lower quality of life scores in both PCS and MCS domains than patients with controlled asthma (Table 4). 
Table 5. Analysis of a correlation between the quality of life score according to the SF-36 and the level of anxiety

\begin{tabular}{|c|c|c|c|c|}
\hline & \multicolumn{3}{|c|}{ HADS - diagnosis (C) } & \multirow{2}{*}{$\begin{array}{c}\text { Comparison } \\
\mathbf{P}\end{array}$} \\
\hline & $\begin{array}{c}\text { No } \\
\text { anxiety }\end{array}$ & $\begin{array}{c}\text { Probable } \\
\text { anxiety }\end{array}$ & $\begin{array}{l}\text { Definite } \\
\text { anxiety }\end{array}$ & \\
\hline $\begin{array}{l}\text { SF-36 PCS } \\
\text { mean } \pm \text { SD }\end{array}$ & $\begin{array}{c}n=13 \\
64.1 \pm 15.1\end{array}$ & $\begin{array}{c}n=12 \\
52.9 \pm 27.2\end{array}$ & $\begin{aligned} n & =8 \\
59.4 & \pm 19.1\end{aligned}$ & 0.629 \\
\hline \multirow[t]{3}{*}{$\begin{array}{l}\text { SF-36 MCS } \\
\text { mean } \pm \text { SD }\end{array}$} & $\begin{array}{c}n=13 \\
65.5 \pm 16.1\end{array}$ & $\begin{array}{c}n=12 \\
59.5 \pm 23.7\end{array}$ & $\begin{aligned} n & =8 \\
49.8 & \pm 18.1\end{aligned}$ & 0.237 \\
\hline & \multicolumn{3}{|c|}{ HADS — diagnosis (U) } & \multirow{2}{*}{$\begin{array}{c}\text { Comparison } \\
\mathbf{P}\end{array}$} \\
\hline & $\begin{array}{c}\text { No } \\
\text { anxiety }\end{array}$ & $\begin{array}{c}\text { Probable } \\
\text { anxiety }\end{array}$ & $\begin{array}{l}\text { Definite } \\
\text { anxiety }\end{array}$ & \\
\hline $\begin{array}{l}\text { SF-36 PCS } \\
\text { mean } \pm \text { SD }\end{array}$ & $\begin{array}{c}n=13 \\
54.8 \pm 26.2\end{array}$ & $\begin{array}{c}n=17 \\
45.6 \pm 23.9\end{array}$ & $\begin{array}{c}n=33 \\
30.8 \pm 16.3\end{array}$ & 0.008 \\
\hline $\begin{array}{l}\text { SF-36 MCS } \\
\text { mean } \pm \text { SD }\end{array}$ & $\begin{array}{c}n=13 \\
62.7 \pm 21.2\end{array}$ & $\begin{array}{c}n=17 \\
53.2 \pm 20.0\end{array}$ & $\begin{array}{c}n=33 \\
40.5 \pm 19.4\end{array}$ & 0.006 \\
\hline
\end{tabular}

HADS — Hospital and Depression Scale; SF-36 — Short Form 36; PCS — Physical Component Score; MCS — Mental Component Score

The analysis of the correlations between the quality of life assessed with the SF-36 and the level of anxiety measured with the HADS showed that there was no correlation between the quality of life in PCS and MCS domains and the level of anxiety (Table 5).

In the group of patients with uncontrolled asthma, on the other hand, the quality of life was statistically significantly lower in PCS domain (no anxiety 54.8 , probable anxiety 45.6 , and definite anxiety 30.8; p = 0.008) and MCS domain (no anxiety 62.7 , probable anxiety 53.2 , and definite anxiety $40.5 ; \mathrm{p}=0.006$ ) proportionally to the level of anxiety. It should be said that patients from group U with a diagnosis of definite anxiety according to the HADS had lower quality of life than those from group $C$ (Table 5).

A one-factor quality of life analysis in relation to additional variables potentially having an influence on quality of life is shown in table 6 . The statistically significant data $(p<0.05)$ were written with bold font.

In the one-factor analysis, lower quality of life in PCS domain was noted in patients with uncontrolled asthma $(39.8 \pm 22.7$ vs. $58.9 \pm 21.1)$, women $(41.8 \pm 21.7$ vs. $53.9 \pm 25.6)$, patients with a diagnosis of chronic severe asthma (32.6 \pm 20.6 vs. $63.8 \pm 21.6)$, smokers $(29.7 \pm 23.1$ vs. $50.4 \pm 23.3$ ), physically inactive patients ( $37.7 \pm$ 26.8 vs. $52.3 \pm 19.8$ ), patients with a diagnosis of definite depression (38.0 \pm 22.8 vs. $57.6 \pm 23.6$ ), and those with a diagnosis of definite anxiety (36.4 \pm 20.2 vs. $59.5 \pm 21.5$ ) (Table 6).

The analysis revealed lower quality of life in MCS domain among patients with uncontrolled asthma (48.5 \pm 21.6 vs. $59.5 \pm 20.0)$, women ( 46.8 \pm 20.9 vs. $61.4 \pm 19.9$ ), patients with a diagnosis of chronic severe asthma ( $42.8 \pm 20.9$ vs. $68.1 \pm 18.6)$, patients with a diagnosis of definite depression (41.8 \pm 19.2 vs. $64.1 \pm 18.6$ ), and those with a diagnosis of definite anxiety ( $42.3 \pm 19.3$ vs. $64.1 \pm 18.5$ ) (Table 6).

\section{Discussion}

Quality-of-life studies are a precious complement to medical examination, especially in chronic diseases, which require total involvement of a patient in the therapeutic process.

For its chronic and changeable course, bronchial asthma can affect patients' general satisfaction and quality of life. On the other hand, a number of factors contributing to satisfaction and quality of life may influence the course of the disease. Available reports show that despite modern treatment, full control of symptoms is not achieved in all patients [14-16].

It is essential to show a relationship between quality of life and other objective results of examinations performed to evaluate functions of an organism and efficiency of the therapy.

The study presented here confirmed that patients with uncontrolled asthma had lower quality of life according to the SF-36 questionnaire. They obtained lower scores for both physical and mental health. The relationship between asthma control and quality of life has been documented in literature [17-20].

Sousa [16] reported on a strong correlation between asthma control and quality of life. Factors which correlated with asthma control included: 
Table 6. Mean scores of PCS and MCS domains in relation to baseline variables analyzed (one-factor analysis)

\begin{tabular}{|c|c|c|}
\hline Qualitative factor & $\begin{array}{c}\text { SF-36 PCS } \\
\text { mean } \pm \text { SD }\end{array}$ & $\begin{array}{l}\text { SF-36 MCS } \\
\text { mean } \pm S D\end{array}$ \\
\hline \multicolumn{3}{|l|}{ Type of asthma: } \\
\hline controlled C $(n=33)$ & $58.9 \pm 21.1$ & $59.5 \pm 20.0$ \\
\hline uncontrolled $U(n=63)$ & $39.8 \pm 22.7$ & $48.5 \pm 21.6$ \\
\hline Mann-Whitney U test, a: $p$ & $<0.001$ & 0.023 \\
\hline \multicolumn{3}{|l|}{ Gender: } \\
\hline women $(n=60)$ & $41.8 \pm 21.7$ & $46.8 \pm 20.9$ \\
\hline men $(n=36)$ & $53.9 \pm 25.6$ & $61.4 \pm 19.9$ \\
\hline Mann-Whitney U test, a: p & 0.024 & 0.002 \\
\hline \multicolumn{3}{|l|}{ Asthma severity level: } \\
\hline intermittent $(n=12)$ & $63.8 \pm 21.6$ & 68. \pm 18.6 \\
\hline chronic mild $(n=32)$ & $50.1 \pm 22.5$ & $57.3 \pm 21.3$ \\
\hline chronic moderate $(n=26)$ & $47.4 \pm 23.5$ & $48.3 \pm 19.0$ \\
\hline chronic severe $(n=26)$ & $32.6 \pm 20.6$ & $42.8 \pm 20.9$ \\
\hline Kruskal-Wallis test: $p$ & 0.001 & 0.003 \\
\hline \multicolumn{3}{|l|}{ Smoking: } \\
\hline no $(n=57)$ & $50.4 \pm 23.3$ & $54.6 \pm 21.3$ \\
\hline no more $(30)$ & $43.6 \pm 23.4$ & $50.7 \pm 19.6$ \\
\hline yes $(n=9)$ & $29.7 \pm 23.1$ & $42.5 \pm 28.3$ \\
\hline Kruskal-Wallis test: $p$ & 0.036 & 0.334 \\
\hline \multicolumn{3}{|l|}{ Physical activity: } \\
\hline no $(\mathrm{n}=39)$ & $37.7 \pm 26.8$ & $47.5 \pm 24.5$ \\
\hline yes $(n=57)$ & $52.3 \pm 19.8$ & $55.5 \pm 18.9$ \\
\hline Mann-Whitney U test, $\mathrm{p}$ & 0.001 & 0.112 \\
\hline \multicolumn{3}{|l|}{ HADS results — depression: } \\
\hline no diagnosis of depression $(\mathrm{n}=26)$ & $57.6 \pm 23.6$ & $64.1 \pm 18.6$ \\
\hline probable depression $(n=29)$ & $48.0 \pm 21.7$ & $56.5 \pm 21.0$ \\
\hline definite depression $(n=41)$ & $38.0 \pm 22.8$ & $41.8 \pm 19.2$ \\
\hline Kruskal-Wallis test: $\mathbf{p}$ & 0.004 & $<0.001$ \\
\hline \multicolumn{3}{|l|}{ HADS results — anxiety: } \\
\hline no diagnosis of anxiety $(n=26)$ & $59.5 \pm 21.5$ & $64.1 \pm 18.5$ \\
\hline probable anxiety $(\mathrm{n}=29)$ & $48.6 \pm 25.1$ & $55.8 \pm 21.4$ \\
\hline definite anxiety $(n=41)$ & $36.4 \pm 20.2$ & $42.3 \pm 19.3$ \\
\hline Kruskal-Wallis test: $p$ & 0.001 & $<0.001$ \\
\hline
\end{tabular}

HADS — Hospital and Depression Scale; SF-36 — Short Form 36; PCS — Physical Component Score; MCS — Mental Component Score

gender, co-existing diseases, respiratory efficiency, and asthma severity. Furthermore, gender and severity of asthma were recognized in his study as predictors of a lower quality of life. In the study described in this article, one-factor analysis revealed that both female gender and asthma severity were factors lowering quality of life in PCS and MCS domains. According to Laforest et al. [21] female gender, residence in a rural area, and a low level of education were predictors of a lower quality of life among asthma patients.

Findings of Federman et al. [22] show that there is a relationship between low health awareness and poor asthma control, a higher number of visits to family practitioner, and more frequent hospitalizations. In the presented study, almost $40 \%$ of patients with uncontrolled asthma had six or more stays in hospital due to asthma. At 
the same time, they paid regular visits to the Allergology Outpatient Clinic definitely rarer than patients with controlled asthma.

In the study conducted by Marinez-Mpragon et al. [3] control of symptoms and education on asthma self-control were mentioned as factors having substantial influence on asthma. In the presented one-factor analysis, uncontrolled asthma was a determinant significantly lowering quality of life in PCS and MCS domains.

Nogueira [23] claims that next to secondhand smoking, taking drugs, and professional activity, the level of education is a statistically significant predictor of low asthma control and low quality of life. In the presented one-factor analysis, smoking was an important predictor of a lower quality of life in PCS domain.

In this study, the lower quality of life in the group of patients with uncontrolled asthma can be associated with their older age, a lower level of education, the lack of professional activity, and in a vast majority - a diagnosis of moderate and severe asthma. Moreover, patients with uncontrolled asthma suffered from asthma for a longer time, had more severe daytime and night-time symptoms, were more often hospitalized, and paid rarer visits to a specialist outpatient clinic. Patients with uncontrolled asthma were nearly 10 years older than those with controlled asthma (average age 58 years). It has been demonstrated in our previous studies, that age over 50 years is a negative contributor to physical and mental functioning of patients. The quality of life assessed with the SF-36 questionnaire revealed statistically significant differences compared to patients below 50 years of age [24].

In this study, the average duration of the disease in the group with uncontrolled asthma was 12.7 years, i.e. over five years more than in the group with controlled asthma. Our other studies showed that people who had asthma for over 10 years assessed their quality of life in the PF domain of the SF-36 considerably lower than those who did not suffer from this disease for such a long time [25].

One more factor reducing patients' ability to comply with therapeutic recommendations, and lowering their quality of life is first- and second -hand smoking $[15,23]$. In the presented study, more than $14 \%$ of patients with uncontrolled asthma were heavy smokers and more than 38\% gave up smoking. Emphasis should be given to the fact that smoking worsens control of asthma, makes its course more serious, and contributes to the necessity for more intensive pharmacological treatment [26].

In recent years, attention has been paid to the problem of symptom control in bronchial asthma. The concept of treatment efficiency assessment based on determination of the level of the disease control was included in the GINA guidelines. Classification of asthma severity grounded exclusively on the frequency of symptoms and the assessment of functional respiratory parameters ignores many aspects which are important for patients and may substantially decrease their quality of life and the possibility of treatment.

Somatic disease is a strong mental strain for patients. Stress caused by chronic disease and paroxysmal dyspnea results in emotional disorders. Lower mood and extreme emotions may cause asthmatic bouts, which in turn increases anxiety [8, 10, 27]. Respiratory disorders in the course of bronchial asthma belong to physiological mechanisms of depression and anxiety development [8, 28].

According to the outcomes of this study, depression occurred both in patients with controlled and uncontrolled asthma, however the latter had more severe symptoms (10.9 vs. 8.9 ). Nevertheless, the differences were statistically insignificant. Anxiety measurement performed with the HADS revealed statistically significantly higher levels of anxiety in the group of patients with uncontrolled asthma (definite anxiety was diagnosed in over a half of the patients).

Available reports confirm higher anxiety and depression levels in patients with severe symptoms and a serious course of asthma [29]. According to Lewandowska et al. [30], depression and anxiety syndromes are jointly responsible for the occurrence of acute dyspnea attacks.

The analysis of a correlation between depression and quality of life proved a statistically significant correlation in MCS domain both in patients with controlled and uncontrolled asthma. A correlation between quality of life and depression in PCS domain was only found in patients with uncontrolled asthma.

The analysis of a correlation between anxiety and quality of life also revealed a statistically significant correlation in PCS and MCS domains, but only in the group with uncontrolled asthma. It was observed that the quality of life in both domains was statistically significantly decreasing along with an increase in the level of anxiety. In the one-factor analysis, diagnoses of definite anxiety and depression negatively affected the quality of life in PCS and MCS domains. 
In their study on a group of 715 patients with bronchial asthma, aged 22-44 years, Leander et al. [31] found a statistical correlation between anxiety and depression and the report of asthma symptoms, such as attacks of dyspnea after activity and waking with attacks of dyspnea. However, there was no significant correlation between anxiety or depression and a self-reported diagnosis of asthma or objective asthma-related variables, such as peak flow variability or response to methacholine. When evaluating the combined influence of psychological factors and objective variables, the HADS correlated independently with reported wheezing, waking with attacks of dyspnea, waking with chest tightness, attacks of dyspnea when at rest, and attacks of dyspnea after activity. The authors, however, did not analyze effects of the disease control on the levels of depression and anxiety.

As evidenced by the study of Hasler et al. [32], severe asthma symptoms contribute to the occurrence of panic attacks. Other contributors mentioned by these authors are: age, anxiety, smoking, alcohol abuse, and family history of asthma.

Feldman [33] confirmed a lower quality of life among people with mood disorders (panic attacks) irrespective of asthma severity, sociodemographic factors, and respiratory efficiency.

Schneider et al. [34], on the other hand, proved that depression and not panic attacks is a factor which may have an influence on the assessment of quality of life by asthma patients.

Likewise our results, findings of Kullowatz [35] confirmed effects of depression and anxiety on quality of life. In his study, anxiety was a factor negatively affecting quality of life in a psychological domain, while depression lowered quality of life in both the physical and psychological domains.

Available literature shows that patients with asthma more often suffer from severe psychological disorders and more often experience their negative effects on quality of life [36-38].

Urrutia et al. [39] shows that comorbidities with asthma and anxiety and depression may affect control of disease symptoms. Anxiety and depression is also a factor which affects quality of life of these patients. In our study we also show the impact of depression and anxiety measured with HADS scale on the quality of life of asthmatic patients.

Pommer et al. [40] assert that mood disorders and anxiety are not determined exclusively by symptoms of disease or current health status, but also depend on individual personality traits.
It should be remembered that in the presented study the majority of patients with controlled asthma were younger, better educated, professionally active, and non-smoking. Such a profile of a patient may confirm that ability to cope with stress and mood disorders is conditioned by individual factors.

The outcomes of this study highlight the importance of depression in asthma management. Even after controlling for symptom severity and anxiety, depression is associated with a decrease in general and asthma-specific quality of life, greater intake of corticosteroids, and marginally increased hospitalization. Asthma patients should be included in routine screening for depression in hospital and primary care to identify those of them who need adjunctive behavioral therapy or psychiatric intervention.

\section{Conclusions}

1. Asthma control significantly improves quality of life.

2. Anxiety and depression are found in asthma patients, with higher severity observed in patients with uncontrolled asthma.

3. Female gender, the level of asthma control, asthma severity, smoking, as well as diagnoses of anxiety and depression are predictors of a significantly lower quality of life in asthma.

\section{Conflict of interest}

The authors declare no conflict of interest.

\section{References:}

1. Kroegel C. Global Initiative for Asthma (GINA) guidelines: 15 years of application. Expert Rev Clin Immunol 2009; 5: $239-249$.

2. Schipper H. Quality of Life Principle of the clinical paradigm. J Psychosocial Oncol 1990; 8: 171-185.

3. Martinez-Moragon E, Palop M, de Diego A et al. Factors affecting quality of life of asthma patients in Spain: The importance of patient education. Allergol Immunopathol (Madr.) 2013; 42: 476-484.

4. Maine Center for Disease Control and Prevention. A Division of the Maine Department of Health and Human Services: Maine Asthma Prevention and Control Program-Action Menagment Plus. 2012

5. Holley AD, Boots RJ. Review article: management of acute severe and near-fatal asthma. Emerg Med Australas 2009; 21: 259-68.

6. Agarwal R, Dhooria S, Aggarwal AN et al. Guidelines for diagnosis and management of bronchial asthma: Joint ICS/NCCP (I) recommendations. Lung India 2015; 32 (Suppl 1): 3-42.

7. O’Byrne P. Global guidelines for asthma managment. Pol Arch Med Wewn 2010; 120: 511-517.

8. Talarowska M, Florkowski A, Gałecki P et al. Rola zmiennych psychologicznych w powstawaniu i przebiegu astmy oskrzelowej oraz funkcjonowanie poznawcze pacjentów. Pneumonol Alergol Pol 2009; 77: 554-559. 
9. Okelo SO, Wu AW, Krishnan JA et al. Emotional quality of life and outcomes in adolescencents with asthma. J Pediatr 2004; 145: $523-529$.

10. Alvarez G, Fitzgerald J. A systematic review of the psychological risk factors associated with near fatal asthma or fatal asthma. Respir 2007; 74: 228-236.

11. Nathan RA, Sorkness CA, Kosinski M et al. Development of the asthma control test: a survey for assessing asthma control. J Allergy Clin Immunol 2004; 113: 59-65.

12. Tylka J, Piotrowicz R. Kwestionariusz oceny jakości życia SF36 wersja polska. Kardiol Pol 2009; 67: 1166-1167.

13. Zigmond AS, Snaith RP. The hospital anxiety and depression scale. Acta Psychiatr Scand 1983; 67: 361-370.

14. Gaude GS, Hattiholi J, Chaudhury A. Role of health education and self-action plan in improving the drug compliance in bronchial asthma. J Family Med Prim Care 2014; 3: 33-38.

15. Horne R. Compliance, adherence and concordance: implications for asthma treatment. Chest 2006; 130 (Suppl 1): 65-72.

16. Correia de Sousa J, Pina A, Margarida Cruz A et al. Asthma control, quality of life and the role of patient enablement: a cross - sectional observational study. Prim Care Respir J 2013; 22: $181-187$.

17. Siroux V, Boudier A, Anto JM, Quality-of-life and asthma-severity in general population asthmatics: results of the ECRHS II study. Allergy 2008; 63: 547-554.

18. Schatz M, Mosen DM, Kosinski M et al. The relationship between asthma-specific quality of life and asthma control. J Asthma 2007; 44: 391-395.

19. Pereira ED, Cavalcante AG, Pereira EN et al. Asthma control and quality of life in patients with moderate or severe asthma. J Bras Pneumol 2011; 37: 705-711.

20. Alpaydin AO, Bora M, Yorgancioglu A et al. Asthma control test and asthma quality of life questionnaire assotiation in adults. Iran J Allergy Asthma Immunol 2012; 11: 301-307.

21. Laforest L, Bousquet J, Neukirch F et al. Influence of sociodemographic factors on quality of life during pollen season in seasonal allergic rhinitis patients. Ann Allergy Asthma Immunol 2005; 95: 26-32.

22. Federman AD, Wolf MS, Sofianou A et al. Asthma outcomes are poor among older adults with low health literacy. J Asthma 2014; 51: 162-167.

23. Nogueira Katia T, Silva JR, Lopes CS. Quality of life of asthmatic adolescents: assessment of asthma severity, comorbidity, and life style. J Pediatr (Rio J) 2009; 85: 523-530.

24. Uchmanowicz I, Fal AM, Jankowska-Polańska B et al. Czy płeć wpływa na wyniki jakości życia chorych na astmę oskrzelową? Współczesna Alergologia Info 2011; VI: 46-51.

25. Uchmanowicz I, Jankowska B, Panaszek B et al. Wpływ czynników społeczno-demograficznych na jakość życia chorych na astmę oskrzelową. Współczesna Alergologia Info 2010; V: $57-65$.

26. Wytrychowski K, Hans-Wytrychowska A. The impact of tobacco smoking and socio-economic factors on asthma control. Współczesna Alergologia Info 2010; V: 132-137.

27. Bateman ED, Hurd SS, Barnes PJ et al.Global strategy for asthma management and prevention: GINA executive summary. Eur Respir J 2008; 31: 143-178.

28. Report National Health, Lung and Blood Institute 2007. National Asthma Education and Prevention Program: Guidelines for the Diagnosis and Management of Asthma.

29. Potoczek A. Różnice w nasileniu i współwystępowaniu objawów zespołu lęku napadowego i depresji w astmie ciężkiej i trudnej oraz w astmie $\mathrm{z}$ nadwrażliwością na aspirynę (aspirynowej). Psychiatr Pol 2011; XLV: 473.

30. Lewandowska K, Kuziemski K, Górska L et al. Jakość życia u chorych na astmę oskrzelową. Pol Med Paliatywna 2006; 2: 71-75.

31. Leander M, Lampa E, Rask-Andersen A et al. Impact of anxiety and depression on respiratory symptoms. Respir Med 2014; 108: $1594-1600$.

32. Hasler G, Gergen PJ, Kleinbaum DG et al. Asthma and panic in young adults: a 20-year prospective community study. Am J Respir Crit Care Med 2005; 171: 1224-1230.

33. Feldman JM, Lehrer PM, Borson S et al. Health care use and quality of life among patients with asthma and panic disorder. J Asthma 2005; 42: 179-185.

34. Schneider A, Lowe B, Meyer FJ Et al. Depression and panic disorder as predictors of health outcomes for patients with asthma in primary care. Respir Med 2008; 3: 3589-3566.

35. Kullowatz A, Kanniess F, Dahme B et al. Association of depression and anxiety with health care use and quality of life in asthma patients. Respir Med 2007; 101: 638-644.

36. Van Lieshouta RJ, MacQueenb GM. Relations between asthma and psychological distress: an old idea revisted. Bienenstock J (ed.). Allergy and the Nervous System. Chem Immunol Allergy. Basel, Karger 2012; 98: 1-13.

37. Nogueira KT, Lopes CS. The association between common mental disorders and quality of life in adolescents with asthma. Rev Bras Epidemiol 2010; 13: 1-11.

38. Lavoie KL, Cartier A, Labrecque M. Are psychiatric disorders associated with worse asthma control and quality of life in asthma patients? Respir Med 2005; 99: 1249-1257.

39. Urrutia I, Aguirre U, Pascual S et al. Impact of anxiety and depression on disease control and quality of life in asthma patients. J Asthma 2012; 49: 201-208.

40. Pommer AM, Pouwer F, Denollet J et al. Managing co-morbid depression and anxiety in primary care patients with asthma and/or chronic obstructive pulmonary disease: study protocol for a randomized controlled trial. Trials 2012; 11: 6 . 